\title{
KAJIAN SISTEM MANAJEMEN K3 DAN TINGKAT KECELAKAAN KERJA PADA PEKERJAAN STRUKTUR BAJA DI PLTU TANJUNG JATI B UNIT 5 \& 6 JEPARA
}

\author{
Khotibul Umam ${ }^{1}$, Nur Hidayati ${ }^{2}$, Yayan Adi Saputro ${ }^{3}$, Dwika Fatimatuz Zaroh ${ }^{4}$, \\ Decky Rochmanto ${ }^{5}$ \\ Prodi Teknik Sipil Fakultas Sains \& Teknologi, Universitas Islam Nahdlatul Ulama Jepara. \\ umam.t.sipil@unisnu.ac.id
}

\begin{abstract}
Safety work management system at the company is very influential in preventing work accidents. Low awarness of workers level of law enforcement provided by the government, it can cause the application of regulations is not optimal, so that it can cause a high level of work accident. For this reason, it is necessary to conduct further studies on the safety work manajemen system. and do the analysis to determine the effectiveness of safety work management and occupational accident in a company. this research was conducted on PLTU Tanjung Jati B unit 5\&6 development project. This reseacrh uses questionnaires to collect the data. the data is processed using the SPSS application with linear regression analysis. The results from this reseach is safety work manajemen system have a influance on the level of occupational accidents if applied simultaneously. The results of the simulation test are $F$ count $=3,24 \geq 3,09 \mathrm{~F}$ table, and occupational accidents that occur have no relationship with the safety work management system and the safety work program. The result in anova table have a velue Sig $=0,291=29,1 \%>5 \%$ is nonlinear and multiple correlation analysis $T$ $=0,25$, there is no strong relation. Accidents that often occur can be categorized in human factor theory.
\end{abstract}

Keywords: system, safety, accident, regression

\begin{abstract}
Abstrak
Sistem manajemen keselamatan kerja di perusahaan sangat berpengaruh dalam mencegah kecelakaan kerja. Rendahnya kesadaran petugas tentang tingkat penegakan hukum yang diberikan oleh pemerintah, dapat menyebabkan penerapan peraturan tidak optimal, sehingga dapat menyebabkan tingkat kecelakaan kerja yang tinggi. Untuk alasan ini, perlu untuk melakukan studi lebih lanjut tentang sistem manajemen pekerjaan keselamatan. dan melakukan analisis untuk menentukan efektivitas manajemen keselamatan kerja dan kecelakaan kerja di perusahaan. Penelitian ini dilakukan pada proyek pengembangan PLTU Tanjung Jati B unit $5 \& 6$. Penelitian ini menggunakan kuesioner untuk mengumpulkan data. data diolah menggunakan aplikasi SPSS dengan analisis regresi linier. Hasil dari penelitian ini adalah sistem manajemen keselamatan kerja memiliki pengaruh pada tingkat kecelakaan kerja jika diterapkan secara bersamaan. Hasil uji simulasi adalah $\mathrm{F}$ hitung $=3,24 \geq 3,09 \mathrm{~F}$ tabel, dan kecelakaan kerja yang terjadi tidak ada hubungan dengan sistem manajemen kerja keselamatan dan program kerja keselamatan. Hasil pada tabel anova memiliki nilai Sig $=0,291=29,1 \%>5 \%$ adalah nonlinier dan analisis korelasi berganda $\mathrm{T}=0,25$, tidak ada hubungan yang kuat. Kecelakaan yang sering terjadi dapat dikategorikan dalam teori faktor manusia.
\end{abstract}

Kata kunci: sistem, keselamatan, kecelakaan, regresi

\section{PENDAHULUAN}

Dalam sebuah proyek, Keselamatan

Dan Kesehatan Kerja sangatlah penting dikarenakan permasalahan ini menyita banyak perhatian dari berbagai organisasi dikarenakan mencakup dari segi biaya serta manfaat ekonomi, aspek hukum, kemanusiaan dan pertanggung jawaban serta citra dari organisasi itu sendiri. Kecelakaan kerja sering terjadi akibat dari kurang terpenuhinya persyaratan dalam pelaksanaan Keselamatan dan Kesehatan Kerja (K3). Rendahnya kesadaran pekerja atau masyarakat terhadap masalah kecelakaan 
kerja serta rendahnya suatu tingkat penegakan hukum yang diberikan oleh pemerintah, sehingga menyebabkan penerapan peraturan pada keselamatan kerja yang masih belum maksimal, sehingga mengakibatkan terjadinya Kecelakaan Kerja yang masih tinggi. Dahulu, para ahli menganggap Kecelakaan Kerja yang telah terjadi disebabkan oleh pekerja itu sendiri yang salah. Namun, sekarang anggapan itu sudah bergeser bahwa suatu kecelakaan kerja bisa terjadi bersumber pada faktor dari organisasi dan Manajemen.

Pada salah satu perusahaan atau kontraktor yang berkontribusi dalam pembangunan proyek PLTU Tanjung Jati B unit 5\&6 memiliki pekerja lebih dari 1500 orang. Pada pekerjaan baja terdapat pekerja sebanyak 150 orang yang tentunya memiliki beragam resiko kecelakaan kerja. Dalam sebuah pekerjaan tentunya perusahaan memiliki sistem manajemen keselamatan kerja yang bertujuan untuk mengatur para pekerja, tidak hanya mengatur jalannya sebuah pekerjaan namun juga bertanggungjawab atas suatu keselamatan kerja para pekerjanya.

1. Berdasarkan dari uraian masalah yang telah dijelaskan, penulis dapat merumuskan masalah sebagai berikut :

2. Bagaimana Sistem Manajemen Keselamatan Dan Kesehatan Kerja (K3) pada proyek pembangunan di PLTU Tanjung Jati $B$ unit $5 \& 6$ ?

Apakah terdapat hubungan dari Sistem Manajemen K3 terhadap tingkat kecelakaan kerja yang terjadi pada proyek Pembangunan PLTU Tanjung Jati B Unit 5\&6?

Adapun tujuan dari penelitian ini adalah:

1. Mengetahui Sistem Manajemen Keselamatan Dan Kesehatan Kerja (K3) yang diterapkan pada Proyek Pembangunan PLTU Tanjung Jati B Unit 5 dan 6.

2. Untuk Mengetahui pengaruh sistem manajemen K3 terhadap tingkat Kecelakaan Kerja.

3. Untuk mengetahui hubungan sistem manajemen dan program K3 terhadap kecelakaan kerja yang terjadi.
4. Untuk mengetahui faktor penyebab terjadinya kecelakaan kerja.

\section{TINJAUAN PUSTAKA \\ Proyek Konstruksi}

Proyek konstruksi merupakan kegiatan yang hanya dilakukan dalam sekali dan pada umumnya dalam jangka waktu yang pendek. Dalam rangkaian suatu kegiatan tersebut, juga terdapat sebuah proses dimana yang mengatur sumber daya proyek menjadi suatu hasil dari kegiatan yang berupa bangunan. Pada suatu proses dari rangkaian kegiatan tersebut tentunya melibatkan banyak pihak yang terlibat, baik secara langsung maupun juga tidak langsung.

\section{Keselamatan Dan Kesehatan Kerja (K3)}

Keselamatan Dan Kesehatan Kerja (K3) adalah sebuah faktor yang sangat penting dalam mencapai sasaran tujuan proyek. Hasil yang maksimal dalam mutu, kinerja biaya serta waktu tidak ada artinya jika tingkat dari keselamatan kerja diabaikan. Indikatornya dapat berupa tingkat kecelakaan kerja yang telah meninggal, cacat permanen, serta instalasi proyek yang rusak dan selain kerugian materi yang besar.(Sanjaya, Widhiawati \& Frederika, no date)

Pada dasarnya tujuan dari K3 adalah untuk melindungi para tenaga kerja hak atas keselamatannya dalam melakukan sebuah pekerjaan dan untuk menciptakan tenaga kerja yang produktif serta sehat sehingga upaya untuk mencapai produktifitas yang maksimal oleh perusahaan industri untuk lebih terjamin.(D, 2008)

\section{Kecelakaan kerja}

Kecelakaan kerja merupakan sebuah risiko yang dihadapi oleh setiap pekerja yang melakukan suatu pekerjaan dengan kerugian yang tidak hanya korban jiwa dan materi bagi tenaga kerja dan pengusaha namun juga dapat mengganggu proses produksi secara keseluruhan dan merusak lingkungan yang pada akhirnya dapat berdampak langsung dengan masyarakat sekitar (D, 2008). Untuk memperkecil risiko terjadinya kecelakaan kerja, sejak tahun 1980an pemerintah mengeluarkan peraturan keselamatan kerja secara khusus untuk industri konstruksi, yaitu Peraturan Menteri Tenaga Kerja dan Transmigrasi, No: Per.01/Men/1980. 
Kecelakaan kerja adalah suatu kejadian yang dapat merugikan dan tidak adanya kesengajaan, tidak dapat terduga, dan tidak diharapkan atau direncanakan, (Endroyo, 2006).

Adapun teori tentang faktor (penyebab) terjadinya kecelakaan kerja, antara lain :

1. Teori Kebetulan Murni (Pure Chance Theory) : Kecelakaan dapat terjadi atas kehendak dari Tuhan sehingga tidak adanya pola pikir yang jelas dalam suatu rangkaian peristiwanya, sehingga dapat disimpulkan dengan kecelakaan kerja dapat terjadi secara kebetulan saja.

2. Teori Kecenderungan Belaka (Accident Prone Theory) : Pada tenaga kerja tertentu lebih sering mengalami kecelakaan karena akibat dari sifat pribadinya yang memang lebih cenderung untuk mengalami kecelakaan kerja.

3. Teori Tiga Faktor Utama (Three Main Factors Theory) : Penyebab dari terjadinya kecelakaan kerja adalah faktor dari manusia (pekerja), peralatan, dan lingkungan.

4. Teori Dua Faktor Utama (Two Main Theory) : Kecelakaan kerja terjadi akibat kondisi yang berbahaya (unsafe conditions) dan tindakan maupun perbuatan yang berbahaya (unsafe actions).

5. Teori Faktor Manusia (Human Factor Theory) : Menekankan bahwa kecelakaan kerja dapat terjadi akibat dari faktor yang dilakukan manusia atau pekerja itu sendiri secara langsung maupun tidak langsung. (D, 2008).

\section{Sistem Manajemen Keselamatan Kerja}

Sistem manajemen secara keseluruhan merupakan bagian yang dapat meliputi diantaranya yaitu struktur organisasi, kegiatan perencanaan, tanggung jawab, prosedur, pelaksanaan, proses serta sumber daya yang dibutuhkan untuk melakukan pengembangan dari suatu penerapan. Pencapaian dari pengkajian dan pemeliharaan sebuah kebijakan keselamatan kerja dalam rangka melakukan pengendalian resiko yang berkaitan dengan suatu kegiatan kerja. Guna tercapainya suatu tempat kerja serta lingkungan yang aman serta efisien dan produktif (Sutarto, 2008).

\section{Manajemen Risiko Keselamatan dan Kesehatan Kerja (K3)}

Manajemen Risiko Keselamatan dan Kesehatan Kerja (K3) adalah upaya dalam melakukan pengelolaan suatu risiko guna mencegah terjadinya suatu kecelakaan kerja yang tidak diharapkan secara komprehensif, dan terencana serta terstruktur pada suatu sistem yang baik. Sehingga, memungkinkan dari sistem manajemen untuk melakukan peningkatan hasil dengan cara mengidentifikasi serta menganalisis pada suatu risiko yang ada.

\section{Pengendalian Risiko Keselamatan dan} Kesehatan Kerja (K3)

Pengendalian risiko adalah langkah penting serta penentuan dalam suatu keseluruhan manajemen risiko. Pengendalian risiko sangat berperan dalam proses mengurangi suatu tingkat risiko yang ada hingga pada tingkat terendah atau sampai dengan tingkatan yang mampu ditolerir. Cara melakukan pengendalian risiko yaitu melalui :

1. Eliminasi : pengendalian ini dapat dilakukan dengan cara menghilangkan sumber bahaya (hazard).

2. Substitusi : melakukan pengendalian dengan cara mengubah proses, dengan cara mengganti input dengan yang lebih rendah risikonya.

3. Engineering : mengurangi risiko dengan cara melakukan metode rekayasa teknik yang diterapkan pada alat, mesin, infrastruktur serta lingkungan, maupun bangunan.

4. Administratif : melakukan pengendalian dengan cara membuat prosedur, peraturan dan pemasangan rambu (safety sign), tanda peringatan, training serta melakukan seleksi pada kontraktor, serta material dan mesin, cara mengatasi masalah, dan pelabelan.

5. Alat Pelindung Diri : mengurangi risiko dengan cara penggunaan alat pelindung diri yang sesuai dengan jenis pekerjaan yang sedang dikerjakan.

\section{Analisis Regeresi Linier Berganda}

Analisis regresi adalah analisis yang mengukur pengaruh variabel bebas terhadap variabel terikat (Kaligis and B.F. Sompie, J. Tjakra, 2013). Persamaan regresi linier berganda memiliki makna bahwa dalam 
sebuah persamaan regeresi terdapat satu variabel terikat (dependent) yang disimbolkan dengan $Y$ dan lebih dari satu variabel bebas (independent) yang disimbolkan dengan $X$. Secara umum persamaan regresi linier berganda dirumuskan sebagai berikut :

$$
\begin{aligned}
& \mathrm{Y}=\mathrm{a}+\mathrm{b} 1 \mathrm{X} 1+\mathrm{b} 2 \mathrm{X} 2+\ldots+\mathrm{bnXn} \\
& \text { Keterangan : } \\
& \mathrm{Y} \quad=\text { Variabel Terikat } \\
& \mathrm{Xn} \quad=\text { Variabel Bebas }
\end{aligned}
$$

$\mathrm{a}=$ Nilai konstanta

variabel $\mathrm{Xn}$

bn $=$ Nilai koefisien regresi

Untuk menentukan nilai a dan b1, b2, ...,bn maka digunakan beberapa persamaan regresi linier berganda : $\sum \mathrm{Xn}$

$$
\sum Y=a n+b 1 \sum X 1+b 2 \sum X 2+\ldots+b n
$$

$\Sigma X 1 Y=a \sum X 1+b 1 \sum X 12+b 2 \Sigma$ $\mathrm{X} 1 \mathrm{X} 2+\ldots+\mathrm{bn} \sum \mathrm{X} 1 \mathrm{Xn}$

$$
\Sigma X 2 Y=a \sum X 2+b 1 \sum X 1 X 2+b 2 \Sigma
$$

$\mathrm{X} 22+\ldots+$ bn $\sum \mathrm{X} 2 \mathrm{Xn}$

Analisis Koefisien Korelasi Berganda

Untuk mengetahui hubungan variabel X1 dan X2 dengan variabel $Y$, maka dilakukan dengan cara analisis koefisien korelasi berganda. Pada umumnya, persamaannya adalah :

$$
\mathrm{R}=\sqrt{\frac{\mathrm{b}_{2} \sum \mathrm{X}_{1}+\mathrm{b}_{2} \sum \mathrm{X}_{2} \mathrm{Y}}{\sum \mathrm{Y}^{2}}}
$$

Keterangan :

$\mathrm{R}=$ Nilai korelasi berganda

$\mathrm{Y}=$ Variabel terikat

$\mathrm{X} 1 \mathrm{X} 2=$ Variabel bebas

$\mathrm{b} 1, \mathrm{~b} 2=$ Nilai koefisien regresi variabel $X$

Sebuah koefisien korelasi berganda, memiliki nilai antara 0 hingga 1 . Semakin dekat nilai koefisien dengan angka 1 , semakin baik tingkat hubungan linear antara variabelvariabel yang terikat. Semakin dekat nilai koefisien dengan angka 0, maka semakin buruk hubungan linear diantara variabelvariabelnya. Dan apabila sebuah koefisien korelasi berganda bernilai 1, korelasi yang dirujukan disebut sebagai korelasi sempurna (Kaligis and B.F. Sompie, J. Tjakra, 2013).

Analisis Regresi Ganda dengan SPSS

Analisis regresi yang dilakukan untuk mengetahui pengaruh yang lebih dari satu variabel indepen terhadap variabel dependen maka disebut dengan analisis regresi ganda. Misalnya seperti melihat pengaruh variabel independen $\mathrm{x} 1, \mathrm{x} 2, \mathrm{x} 3$ secara bersama-sama terhadap variabel dependen $y$. Hal ini dapat digambarkan dengan :

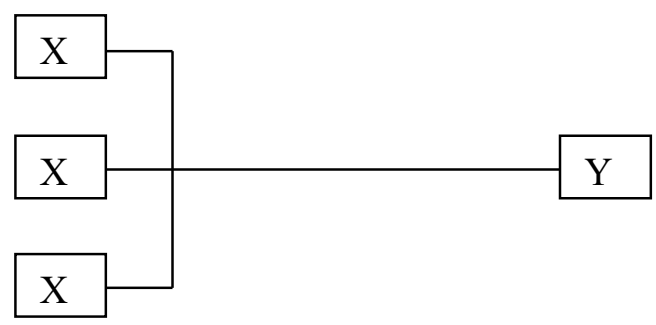

Sehingga model regresi ganda dapat didefinisikan sebagai berikut :

$$
y=\beta 0+\beta 1 \times 1+\beta 2 x 2+\ldots . \beta n x n+\varepsilon
$$

atau dapat juga ditulis dengan persamaan matriks :

$Y=X \beta+\varepsilon$,

Dimana matriks $X$ berordo $n x(p+1)$. Dengan teorema kuadrat terkecil OLS diperoleh penaksir beta dengan rumus :

$\beta=\left(X^{\prime} X\right)-1 X^{\prime} Y$,

dimana penaksir beta tersebut memiliki sifat BLUE (best lienear unbiased estimator). Jadi dia adalah penaksir terbaik yang tidak biasa apabila semua persyaratan dipenuhi (Sukestiyarno, 2017).

Langkah-langkah dalam melakukan pengujian Analisis Regresi Linier Ganda dengan menggunakan program SPSS adalah sebgai berikut :

Uji Asumsi persyaratan : persyaratan yang harus dipenuhi dalam analisis regresi ganda adalah sama dengan persyaratan pada analisis regresi sederhana yakni jenis data variabel independen maupun variabel dependen harus interval atau rasio, variabel dependen berdistribusi normal dan varian homogen.

Uji adanya pengaruh : untuk mengetahui adanya hubungan linier dibuat scatter plotnya terlebih dahulu, disini tidak bisa menunjukkan untuk memplot bersamasama untuk dimensi dua. Untuk tujuan hal tersebut kita lakukan plot untuk masingmasing variabel independen satu persatu terhadap variabel dependen. Dalam hal ini kita bisa memprediksi mencari faktor pengaruh yang dominan. 
Selanjutnya untuk proses uji hipotesis variabel independen dan dependen. Apabila hubungan liniearnya sudah teruji diterima, nilai koefisien determinasi R2 akan semakin membesar mendekati $100 \%$ bila variabel independen juga semakin bertambah.

Uji Signifikan

Pengujian Parsial/ indiviual

Pengujian ini dilakukan guna menentukan tingkat signifikannya atau tidaknya masing-masing koefisien dari variabel $\mathrm{X} 1$ dan $\mathrm{X} 2$, yaitu b1 dan b2 secara terpisah terhadap variabel terikat (Y). Pengujian ini dilakukan dengan menggunakan distribusi t. Persamaan umumnya sebagai berikut :

$$
\mathrm{t}=\frac{\mathrm{b}_{\mathrm{n}}}{\mathrm{sb_{n }}}
$$

Keterangan :

$$
\begin{array}{ll}
\mathrm{t} & =\text { Nilai signifikansi } \\
\mathrm{b} & =\text { Nilai koefisien variabel } \mathrm{X} \\
\mathrm{sb} & =\text { Standar eror koefisien regresi } \\
\mathrm{n} & =\text { Jumlah responden }
\end{array}
$$

Kontrol dari pengujian ini yaitu dengan menggunakan tabel distribusi t. Berdasarkan kriteria pengujian dua sisi (Kaligis and B.F. Sompie, J. Tjakra, 2013), jika $t$ hitung < -t tabel atau $t$ hitung $>+t$ tabel, maka terjadi adanya pengaruh yang signifikan antara variabel $\mathrm{X} 1$ dan $\mathrm{X} 2$ terhadap variabel $\mathrm{Y}$.

\section{Pengujian Simultan / Serentak}

Pengujian ini melibatkan dari kedua variabel bebas, yaitu $\mathrm{X} 1$ dan $\mathrm{X} 2$ terhadap variabel terikat yaitu $Y$. Tujuannya yaitu untuk mengetahui tentang ada atau tidaknya suatu pengaruh yang secara signifikan dari kedua koefisien regeresi dari variabel X1 dan X2 (b1 dan b2), secara simultan atau serentak terhadap variabel $Y$. Pengujian dengan cara simultan menggunakan distribusi $F$, yaitu dengan membandingkan antara $F$ hitung dan $\mathrm{F}$ tabel. Persamaan umumnya yaitu :

$$
F=\frac{R^{2}(n-m-1)}{m\left(1-R^{2}\right)}
$$

Keterangan :

$$
\begin{array}{ll}
\mathrm{F} & =\text { Nilai signifikansi } \\
\mathrm{R} & =\text { Koefisien korelasi berganda } \\
\mathrm{n} & =\text { Jumlah responden } \\
\mathrm{m} & =\text { Jumlah variabel bebas }
\end{array}
$$

Kontrol dari pengujian ini dilakukan dengan cara tabel distribusi F. Berdasarkan kriteria pengujian satu sisi kanan (Kaligis and B.F. Sompie, J. Tjakra, 2013), maka terdapat pengaruh yang signifikan jika $F$ hitung $\geq F$ tabel.

Bagian ini berisi rangkuman landasan teori. Penulisan sitasi seperti berikut ini (Engki and Viv, 2014). Jika lebih dari satu penulis ditulis seperti ini (Heriyanto et al, 2008). Jika di awal kalimat bisa ditulis begini. Bishop (1984) menjelaskan bahwa hanya yang tercantum referensinya saja yang ditulis di daftar pustaka.

\section{METODE PENELITIAN}

Lokasi yang digunakan dalam melakukan penelitian adalah proyek dari PLTU Tanjung Jati B unit $5 \& 6$ berlokasi di Desa Tubanan Sekuping, Tubanan Kembang, Jepara 59453 Jawa Tengah. Waktu yang dilakukan dalam melakukan penelitian ini dimulai dari bulan Mei hingga bulan Agustus 2019.

Dalam melakukan penelitian ini, penulis akan menggunakan metode Deskriptif, yaitu metode penelitian yang menggunakan pengumpulan informasi tentang keadaankeadaan yang sedang terjadi. Kemudian dalam penelitian ini digunakan kuisioner sebagai instrumen pengumpulan data. Pengambilan data yang dilakukan dengan cara teknik sampling dengan menggunakan dua variabel yaitu variabel bebas dan variabel terikat. Pertanyaan dalam kuisioner menyangkut tentang sistem manajamen Keselamatan Dan Kesehatan Kerja (K3) yang diterapkan, serta hubungan sistem manajemen terhadap tingkat kecelakaan kerja pada pekerja struktur baja di proyek pembangunan PLTU Tanjung Jati B Unit 5 dan 6.

Dalam melakukan penelitian dilakukan pengumpulan data yang dilakukan di lapangan secara detail agar memperoleh data yang tepat serta akurat dan memenuhi. Teknik pengumpulan data yang digunakan dalam melakukan penelitian ini adalah :

\section{Data Primer}

Data primer adalah data yang secara langsung diperoleh dari responden yaitu pekerja baja berdasarkan kuisioner (daftar pertanyaan) yang akan diisi dengan benar dan kemudian dikembalikan kembali kepada penulis atau peneliti. Kuisioner yang akan disebarkan terdiri dari : 
Data Umum, berisi mengenai data pribadi responden yaitu Nama, umur, pendidikan terakhir, Masa Kerja, jenis proyek yang dikerjakan

Data tentang faktor-faktor yang mempengaruhi dalam pelaksanaan program keselamatan dan kesehatan kerja pada pekerja struktur baja di proyek.

Data mengenai kinerja berdasarkan parameter efisiensi sistem manajemen, efisiensi keselamatan kerja dan tingkat kecelakaan pekerja.

\section{Data Sekunder}

Merupakan data yang diperoleh dengan cara mencari referensi dari berbagai literatul atau sumber melalui berbagai jenis media masa atau media online dan mendatangi langsung ke kantor-kantor atau instansi yang terdapat kaitannya dengan penelitian ini. Dalam melakukan penelitian ini data yang diperlukan adalah data pekerja dan staff-staff terkait guna menganalisis sistem manajemen K3 dan tingkat Kecelakaan Kerja yang terjadi pada pekerja struktur baja.

\section{HASIL DAN PEMBAHASAN}

Dalam melakukan penelitian ini, pengambilan data dilakukan dengan cara teknik sampling dengan menggunakan dua variabel yaitu variabel bebas $(X 1, X 2)$ dan variabel terikat $(Y)$ sehingga $X 1$ untuk Sistem Manajemen, X2 untuk Keselamatan Kerja, dan $Y$ untuk Kecelakaan Kerja. Kemudian penulis melakukan penelitian dengan memberikan Kuisioner kepada pekerja struktur baja, kuisioner yang diberikan tentunya yang berkaitan dengan sistem manajemen dan K3 pada proyek yang sedang dilakukan, dari kuisioner yang telah diberikan kemudian mendapatkan data sebanyak 100 responden.

\section{Analisis Regresi Linier Berganda}

Dikarenakan dalam melakukan penelitian ini menggunakan variabel bebas yaitu dua variabel, maka persamaan umum dari analisis linier berganda yang akan digunakan adalah :

$$
\mathrm{Y}=\mathrm{a}+\mathrm{b} 1 \mathrm{X} 1+\mathrm{b} 2 \mathrm{X} 2
$$

Data statistik yang telah diperoleh kemudian dimasukan kedalam persamaan regresi linier berganda untuk memperoleh nilai a, b1, b2, yaitu sebagai berikut :
$\mathrm{X} 1 \mathrm{X} 2$

$$
\begin{aligned}
& \sum Y=a n+b 1 \sum X 1+b 2 \sum X 2 \\
& 1610=100 a+1629 b 1+1578 b 2 \\
& \sum X 1 Y=a \sum X 1+b 1 \sum X 12+b 2 \sum
\end{aligned}
$$

$26217=1629 \mathrm{a}+26813 \mathrm{~b} 1+25766 \mathrm{~b} 2$

$\Sigma X 2 Y=a \sum X 2+b 1 \sum X 1 X 2+b 2 \sum$

$\mathrm{X} 22$

$25430=1578 \mathrm{a}+25766 \mathrm{~b} 1+25122 \mathrm{~b} 2$

Setelah mendapatkan hasil pesamaan seperti diatas, dilakukan perhitungan dengan metode eliminasi dan subtitusi. Dengan demikian, diperoleh persamaan regresi berganda $Y=15,134+(-0,063) X 1+0,127$ $\mathrm{X} 2$. Sehingga nilai $\mathrm{a}=15,134$, nilai $\mathrm{b} 1=$ 0,063 , dan nilai $b 2=0,127$. Pada perhitungan selanjutnya, nilai konstanta dari (a) diabaikan, karena variabel-variabel yang ada (X1, X2, dan $Y$ ) dianggap memiliki satuan yang sama.

\section{Analisis Koefisien Korelasi Berganda}

Kemudian, untuk mengetahui besarnya hubungan antara variabel bebas (X1 dan $\mathrm{X} 2$ ) dengan variabel terikat $(Y)$ atau sistem manajemen K3 terhadap tingkat kecelakaan kerja yang sering terjadi, sehingga dilakukan analisis koefisien korelasi berganda.

Dalam melakukan analisis data yang digunakan adalah nilai dari data statistik dan nilai koefisien yang didapat dari analisis regresi linier berganda, data yang sudah diperoleh kemudian dimasukan ke dalam rumus seperti berikut :

$$
\begin{aligned}
\mathrm{R} & =\sqrt{\frac{\mathrm{b}_{2} \sum \mathrm{X}_{1}+\mathrm{b}_{2} \sum \mathrm{X}_{2} \mathrm{Y}}{\sum \mathrm{Y}^{2}}} \\
& =\sqrt{\frac{(-1651,671)+(3229,61)}{26068}} \\
\mathrm{R} & =0,25
\end{aligned}
$$

Dari hasil perhitungan diatas, diperoleh nilai koefisien yaitu $R=0,25$ dimana angka tersebut terpaut cukup jauh dari nilai koefisien korelasi yang ditetapkan atau kurang dari 1 . Hal ini menunjukkan bahwa tidak ada hubungan antara sistem manajemen K3 terhadap terjadinya kecelakaan kerja.

Analisis Regresi Ganda (SPSS)

Dalam melakukan analisis regresi ganda yang diolah menggunakan program SPSS, persamaan umum dari analisis linier berganda yang akan digunakan sama seperti sebelumnya, yaitu :

$$
\mathrm{Y}=\mathrm{a}+\mathrm{b} 1 \mathrm{X} 1+\mathrm{b} 2 \mathrm{X} 2
$$

Data statistik yang telah diperoleh kemudian dimasukan kedalam persamaan 
regresi linier berganda untuk memperoleh nilai $a, b 1$, b2, dalam melakukan pengujian nilai tersebut, data diolah menggunakan program SPSS dan mendapatkan hasil seperti berikut : Interpretasi dalam pembacaan output untuk proses uji hipotesis, dapat dilakukan dengan cara :

Model regresi $y=\beta 0+\beta 1 \times 1+\beta 2 \times 2+\varepsilon$ Bentuk hipotesis model linier :

$\mathrm{HO}: \beta=\left(\begin{array}{l}\beta 1 \\ \beta 2\end{array}\right)=0$ (persamaan adalah tidak linier atau tidak ada relasi antara $x 1, x 2$, dan y).

$\mathrm{H} 1: \beta=\left(\begin{array}{l}\beta 1 \\ \beta 2\end{array}\right) \neq 0$ (persamaan adalah linier atau ada relasi antara $\mathrm{x} 1$ dan $\mathrm{x} 2$ secara bersama dan y).

Formulasi rancangan analisis : penaksir model linier ganda adalah $\mathrm{y}=\mathrm{a}+\mathrm{bx} 1+\mathrm{cx} 2$, dengan cara uji dua pihak, taraf signifikan $5 \%$. Persamaan regresi berdasarkan pada sampel yang dibaca pada output Coefficient:

Diperoleh nilai $a=15,134$; b1= $-0,063$; dan b2 $=0,127$ (Coefficeints), jadi persamaan regresi adalah :

$$
\mathrm{Y}=\mathrm{a}+\mathrm{b} 1 \mathrm{X} 1+\mathrm{b} 2 \mathrm{X} 2=15,134+(-
$$

$0,063) X 1+0,127 X 2$

Kemudian kita akan uji nilai a, b1, dan b2 tersebut, guna untuk menerima atau menolak hipotesis dibaca tabel perhitungan distribusi $F$ yang tertera pada output tabel ( ANOVA). Pada hasil output data memperoleh nilai $F=1,251$; sig $=0,291$.

Sehingga sig $=0,291=29,1 \%>5 \%$ maka $\mathrm{HO}$ diterima dan menolak $\mathrm{H} 1$, oleh karena itu hasil dari persamaan adalah tidak linier atau $\mathrm{X} 1$ dan $\mathrm{X} 2$ tidak ada hubungan terhadap $Y$, oleh karena itu analisis tidak dapat dilanjutkan ke proses melihat besar pengaruh $\mathrm{X} 1$ dan $\mathrm{X} 2$ terhadap $\mathrm{Y}$.

\section{Uji Signifikansi}

\section{Pengujian Parsial}

Pengujian parsial dilakukan untuk mengetahui atau menentukan tingkat signifikan masingmasing koefisien, yaitu koefisien regresi sistem manajemen (b1) dan K3 (b2) secara terpisah terhadap variabel terikat atau kecelakaan kerja (Y).

Pengujian koefisien b1

Diketahui :

Jumlah responden $(\mathrm{n}): 100$,

Level of significance $(\alpha): 1 \%$,
Sehingga dapat ditentukan $t$ tabel sesuai rumus : ta / 2 ; df (n-2), maka t $1 \% / 2$; df (100 $-2)=\mathrm{t} 0,005 ; \mathrm{df} 98$.

Dengan demikian kita dapat melihat pada tabel distribusi $\mathrm{t}$, maka nilai $\mathrm{t}$ tabel adalah 2,627.

Langkah selanjutnya adalah mencari nilai $\mathrm{t}$ hitung :

$\mathrm{t}=\frac{\mathrm{b}_{1}}{\mathrm{sb}_{1}}=\frac{-0,063}{0,075}=-0,84$

Menentukan $\mathrm{HO}$ dan $\mathrm{Ha}$ :

$\mathrm{HO}=$ nilai koefisien regresi (b1) tidak signifikan atau tidak ada hubungan terhadap $Y$.

$\mathrm{Ha}=$ nilai koefisien regresi (b1) signifikan atau terdapat hubungan terhadap $\mathrm{Y}$.

Kriteria pengujian :

Berdasarkan kriteria pengujia pada dua sisi, maka $\mathrm{HO}$ diterima jika t hitung berada diantara - 2,627 dan +2,627 ; dan HO ditolak jika t hitung $<-2,627$ atau t hitung $>+2,627$.

Sehingga berdasarkan hasil diatas, maka $\mathrm{HO}$ diterima karena nilai tb1 $=-0,84$ berada diantara $-2,627$ dan $+2,627$. Oleh karena itu nilai koefisien regresi (b1) yaitu Sistem manajemen tidak signifikan atau tidak ada hubungan terhadap kecelakaan kerja (Y).

Pengujian koefisien b2

Diketahui :

Jumlah responden $(\mathrm{n}): 100$,

Level of significance $(\alpha): 1 \%$,

Sehingga dapat ditentukan $t$ tabel sesuai rumus : ta $/ 2$; df (n-2), maka t $1 \% / 2$; df (100 $-2)=\mathrm{t} \mathrm{0,005;} \mathrm{df} 98$.

Dengan demikian kita dapat melihat pada tabel distribusi $t$, maka nilai $t$ tabel adalah 2,627.

Langkah selanjutnya adalah mencari nilai $\mathrm{t}$ hitung :

$\mathrm{t}=\frac{\mathrm{b}_{2}}{\mathrm{sb}_{2}}=\frac{0,127}{0,084}=1,51$

Menentukan $\mathrm{HO}$ dan $\mathrm{Ha}$ :

$\mathrm{HO}=$ nilai koefisien regresi (b2) tidak signifikan atau tidak ada hubungan terhadap $Y$.

$\mathrm{Ha}=$ nilai koefisien regresi (b2) signifikan atau terdapat hubungan terhadap $\mathrm{Y}$.

Kriteria pengujian :

Berdasarkan kriteria pengujia pada dua sisi, maka $\mathrm{HO}$ diterima jika t hitung berada diantara - 2,627 dan +2,627; dan HO ditolak jika t hitung $<-2,627$ atau t hitung $>+2,627$. 
Sehingga berdasarkan hasil diatas, maka $\mathrm{H} 0$ diterima karena nilai tb2 $=1,51$ berada diantara $-2,627$ dan $+2,627$. Oleh karena itu nilai koefisien regresi (b2) yaitu K3 tidak signifikan atau tidak ada hubungan terhadap kecelakaan kerja $(\mathrm{Y})$.

Pengujian simultan / serentak (Distribusi F)

Tujuan dari pengujian ini adalah untuk mengetahui ada atau tidaknya pengaruh yang signifikan pada koefisien regresi (b1) dan (b2) secara simultan atau serentak. Pada pengujian ini menggunakan dua variabel bebas sistem manajemen dan K3 terhadap variabel terikat atau kecelakaan kerja.

Menentukan nilai $\mathrm{F}$ tabel

Diketahui :

Jumlah responden $(n): 100$,

Level of significance $(\alpha): 5 \%$,

Degree of freedom / pembilang $(m)=2$,

Penyebut $=\mathrm{n}-\mathrm{m}-1=100-2-1=97$.

Sehingga $F$ tabel $=F 5 \%$; df (2) (97)

$=3,09$

Mencari $\mathrm{F}$ hitung

$\mathrm{F}=\frac{\mathrm{R}^{2}(\mathrm{n}-\mathrm{m}-1)}{\mathrm{m}\left(1-\mathrm{R}^{2}\right)}$

$\mathrm{F}=\frac{0,25^{2}(100-2 \quad)}{2\left(1-0,25^{2}\right)}$

$\mathrm{F}=3,23$

Menentukan $\mathrm{HO}$ dan $\mathrm{Ha}$ :

$\mathrm{HO}=$ nilai koefisien regresi (b1 dan b2) tidak signifikan atau tidak ada hubungan terhadap Y.

$\mathrm{Ha}=$ nilai koefisien regresi (b1 dan b2) signifikan atau terdapat hubungan terhadap $Y$ Kriteria pengujian :

Berdasarkan kriteria pengujian pada satu sisi, maka $\mathrm{H} 0$ diterima jika nilai $\mathrm{F}$ hitung $\leq 3,09$ dan $\mathrm{H} 0$ ditolak jika nilai $\mathrm{F}$ hitung $\geq 3,09$.

Maka hasil dari pengujian simultan (Distribusi F) adalah $\mathrm{HO}$ ditolak, karena $\mathrm{F}$ hitung $=3,23 \geq 3,09 \mathrm{~F}$ tabel. Sehingga nilai koefisien regresi (b1 dan b2) yaitu sistem manajemen dan K3 signifikan atau terdapat hubungan terhadap kecelakaan kerja (Y).

\section{SIMPULAN}

Sistem Manajemen Keselamatan dan Kesehatan Kerja (K3) pada suatu perusahaan sangat berpengaruh dalam mencegah terjadinya suatu risiko atau kecelakaan kerja. Terjadinya kecelakaan kerja tidak hanya dapat mengakibatkan kerugian terhadap diri sendiri atau pribadi, namun juga dapat mengakibatkan kerugian pada perusahaan maupun orang lain. Setelah melakukan penelitian pada proyek pembangunan PLTU Tanjung Jati B unit 5\&6, penulis dapat menyimpulkan bahwa :

1. Pada Proyek Pembangunan PLTU Tanjung Jati $B$ unit $5 \& 6$, perusahaan atau kontraktor sudah memiliki sistem manajemen K3 maupun program K3 dalam melakukan pengendalian risiko yang cukup baik. Hal ini dibuktikan dengan adanya pembaharuan HIRA, Program Kerja, SOP, maupun instruksi kerja yang sudah tidak sesuai.

2. Sistem manajemen K3 memiliki pengaruh terhadap tingkat kecelakaan kerja jika diterapkan secara serentak. Hal ini dibuktikan dengan hasil uji simultan yaitu $\mathrm{F}$ hitung $=3,23 \geq 3,09 \mathrm{~F}$ tabel.

3. Kecelakaan kerja yang terjadi tidak ada hubungannya dengan sistem manajemen dan program $\mathrm{K} 3$, dibuktikan dengan hasil analisis korelasi berganda $R=0,25$ yang artinya tidak ada hubungan yang erat.

4. Menurut pekerja struktur baja, kecelakaan yang sering terjadi diakibatkan oleh kecerobohan pribadi, seperti tidak berhatihati saat mengambil material sehingga terjadi goresan pada tangan, kemudian pada pekerja shift malam adalah sakit demam, flu, batuk, dan angin duduk. Hal ini dapat dikategorikan pada Teori Faktor Manusia (Human Factor Theory).

\section{DAFTAR PUSTAKA}

Andi, Model Persamaan Struktural Pengaruh Budaya Keselamatan Kerja pada Perilaku Pekerja di Proyek Konstruksi. Jurnal Teknik Sipil Volume 12 No. 3, Juli 2005.

Bambang, Peranan Manajemen K3 Dalam Pencegahan Kecelakaan Kerja Konstruksi. Universitas Negeri Semarang, Semarang.

Dameyanti, Implementasi Keselamatan dan Kesehatan Kerja (K3) Pada Proyek Di Kota Bitung. Jurnal Sipil Statik Vol. 2 No. 3, Maret 2014.

Darmawi, H. 1990. Manajemen Risiko. Jakarta : Bumi Aksara.

Ervianto, Wulfram I. 2005. Manajemen Proyek Konstruksi. Andi, Yogyakarta.

Gabby, Manajemen Risiko Kesehatan dan Keselamatan Kerja (K3). Jurnal IImiah 
Media Engineering Vol. 4 No. 4, Desember 2014.

Gempur Santoso, 2004. Manajemen Keselamatan dan Kesehatan Kerja, Cetakan Pertama, Prestasi Pustaka, Jakarta.

Kerzner, H, 1998. Project Management : A System Approach to Planning, Scheduling and Controlling, $5^{\text {th }}$ edition. Canada.

Hinze, W. Jimmie. Construction Safety. Prentice-Hall, Inc. 1997

Mastura, Labombang. 2011. Manajemen Risiko dalam Proyek Konstruksi. Jurnak SMARTek, Vol. 9 No. 1. Pebruari 2011: 3946.

Napitupulu, 1989, Keselamatan Kerja Terpadu dalam Sistem Manajemen, Modul III, GBMPE, Institut Manajemen Proteksi Indonesia, Jakarta.

Peraturan Menteri Tenaga Kerja No: Per.05/Men/1996 mengenai Sistem Manajemen K3.

Raldo, Pengaruh Implementasi Program Keselamatan dan Kesehatan Kerja (K3) Terhadap Produktivitas Kerja. Jurnal Sipil Statik Vol. 1 No. 3, Februari 2013.

Spiegel, M.R. and Stephens L.J., 1999. "Statistik", Terjemahan Wiwit Kastawan dan Irzam Harmein, Erlangga, Jakarta.

Sukaelan, M. 2003. Kecelakaan Kerja. Prosiding Seminar Nasional Keselamatan dan Kesehatan Kerja, Yogyakarta, 20 Sebtember 2003.

Sunyoto, D., 2011. "Analisis Regresi dan Uji Hipotesis”, CAPS., Yogyakarta. 